\title{
Cell-surface expression, progestin binding, and rapid nongenomic signaling of zebrafish membrane progestin receptors $\alpha$ and $\beta$ in transfected cells
}

\author{
Richard Hanna, Yefei Pang ${ }^{1}$, Peter Thomas ${ }^{1}$ and Yong Zhu \\ Department of Biology, East Carolina University, 1000 E. 5th Street, Greenville, North Carolina 27858-4553, USA \\ ${ }^{1}$ Marine Science Institute, University of Texas at Austin, 750 Channelview Drive, Port Aransas, Texas 78373, USA \\ (Requests for offprints should be addressed to Y Zhu; Email: zhuy@mail.ecu.edu)
}

\begin{abstract}
Recently, a unique family of membrane progestin receptors $(\mathrm{mPR} \alpha, \mathrm{mPR} \beta$, and $\mathrm{mPR} \gamma)$ was identified, which may be responsible for mediating rapid, nongenomic actions of progestins in a variety of target tissues. In this study, the $\mathrm{mPR} \alpha$ and $\mathrm{mPR} \beta$ isoforms from zebrafish were shown to be rapidly and specifically activated by the maturation-inducing steroid (MIS) of this species, 4-pregnen-17,20 $\beta$-diol-3-one $(17,20 \beta-\mathrm{DHP})$. The zebrafish $\mathrm{mPR} \alpha$ and a previously uncharacterized $\mathrm{mPR} \beta$ isoform were stably expressed in nuclear progesterone receptor-deficient mammalian breast cancer cells, MDA-MB-231. Expression and surface localization of the receptors were verified by flow cytometry, biotin surface labeling, and Western blotting. Plasma membrane proteins from $\mathrm{mPR} \alpha$ - or $\mathrm{mPR} \beta$-transfected cells showed high affinity $\left(\mathrm{mPR} \alpha, K_{\mathrm{d}} 7 \mathrm{nM} ; \operatorname{mPR} \beta, K_{\mathrm{d}}\right.$ $12 \mathrm{nM}$ ), saturable, displaceable, single-binding sites specific for 17,20 $\beta$-DHP, whereas negligible specific 17,20 $\beta$-DHP binding was observed in nontransfected cells. Progestin treatment caused significant activation of mitogen-activated protein kinase (MAPK) within 5 min in cells transfected with
\end{abstract}

either of the receptors as measured by western blotting and flow cytometry. The rank order of the potencies of several progestins in activating MAPK via $\mathrm{mPR} \alpha$ and $\mathrm{mPR} \beta$ was the same $(17,20 \beta-D H P>$ progesterone $>4$-pregnen-17,20 $\beta, 21$ triol-3-one). Interestingly, the MIS in zebrafish, 17,20ßDHP, was also the most potent inhibitor, among the progestins tested, of adenylyl cyclase activity in cells transfected with either of the receptors. This progestin significantly decreased cAMP levels in both $\mathrm{mPR} \alpha-$ and mPR $\beta$-transfected cells in a dose-responsive and timedependent manner. In addition, signaling of the zebrafish $\mathrm{mPR} \alpha$ was blocked by pertussis toxin, implying activation of a $G_{i}$ protein, while sensitivity to pertussis or cholera toxin was not shown with $\mathrm{mPR} \beta$-mediated signaling, possibly indicating that this receptor activates a different pertussis toxin-insensitive $G$ protein. The results of this study suggest that zebrafish $\mathrm{mPR} \alpha$ and $\operatorname{mPR} \beta$ signal similarly upon progestin binding resulting in rapid activation of MAPK and downregulation of adenylyl cyclase activity.

Journal of Endocrinology (2006) 190, 247-260

\section{Introduction}

Steroids have been known to exert nonclassical steroid actions, not involving genomic mechanisms, for over 30 years (Pietras \& Szego 1975, Kostellow et al. 1980). All major classes of steroids have been shown to exert rapid nongenomic actions (Norman et al. 2004). Some specific nongenomic actions of progestins identified thus far include induction of the acrosomal reaction in sperm (Blackmore et al. 1990, Sabeur et al. 1996, Baldi et al. 1998, Luconi et al. 2004), an increase in sperm motility (Thomas et al. 2005), modulation of gonadotropin-releasing hormone discharge in the brain (Majewska et al. 1986, Calogero et al. 1998, Sim et al. 2001), and induction of oocyte maturation in fish and amphibian species (Kostellow et al. 1980, Patiño \& Thomas 1990a, Ferrell 1999). Moreover, steroid-binding moieties with the characteristics of progestin receptors have been detected by radioreceptor assays on plasma membranes prepared from several of these progestin target tissues (Patiño \& Thomas 1990b, Blackmore \& Lattanzio 1991, Falkenstein et al. 1999). Although these studies have provided strong evidence for the existence of rapid, nongenomic progestin actions, and specific membrane receptors through which they can act, many details of this nonclassical steroid mechanism remain unclear. For example, the precise molecular structures of the progestin membrane receptors and their mechanisms of action are unresolved (Losel et al. 2003, Norman et al. 2004).

Recently, a novel family of membrane progestin receptors $(\mathrm{mPR} \alpha, \mathrm{mPR} \beta$, and $\mathrm{mPR} \gamma)$ has been identified, which may be responsible for mediating some of these rapid nongenomic 
progestin actions (Zhu et al. 2003a, 2003b). The mPRs are well conserved across a broad range of vertebrate species from fish to humans, and have similar structures and progestinbinding activities (Zhu et al. 2003a, 2003b). Recombinant $\mathrm{mPR} \alpha$ proteins from seatrout, as well as $\operatorname{mPR} \alpha, \operatorname{mPR} \beta$, and $\mathrm{mPR} \gamma$ proteins from human and mouse have been shown to specifically bind progestins (Zhu et al. 2003a, 2003b). In addition, the mPRs have $G$ protein coupled receptor (GPCR)-like structures, including seven transmembrane domains, N-terminal glycosylation sites, and conserved cysteine residues for disulfide bonding. Despite their similarities to GPCRs, the mPRs have been grouped in a unique receptor class called the progestin and adiponectin receptor (PAQR) family, which is based on seven transmembrane domains and an uncharacterized UPF0073 motif (Fernandes et al. 2005, Tang et al. 2005). It is generally accepted that all GPCRs have seven transmembrane domains with the N-terminus on the outside of the cell and C-terminus on the inside of the cell. However, Tang et al. (2005) have proposed an extracellular C-terminus topology of the PAQR superfamily based on a computer predication. As a result of this unique receptor classification and topology predication, it is difficult to assess whether all members of the receptor family signal and function through typical GPCR pathways.

The spotted seatrout $m P R \alpha$ was the first $\mathrm{mPR}$ to be characterized, and evidence was obtained for its involvement in oocyte maturation in this species (Zhu et al. 2003a). The seatrout $\mathrm{mPR} \alpha$ is localized on the oocyte membrane, its expression in late stage oocytes increases prior to oocyte maturation, and is hormonally upregulated by gonadotropin during oocyte 'priming' (Zhu et al. 2003a). Similar findings have been obtained with the goldfish $\mathrm{mPR} \alpha$, including oocyte membrane localization, inhibition of oocyte maturation by antisense microinjections, and a correlation between receptor protein levels and the ability of the maturationinducing steroid (MIS) to induce oocyte maturation (Tokumoto et al. 2006).

The signaling of seatrout $\mathrm{mPR} \alpha$ is also consistent with previous reports on the intracellular-signaling pathways activated by progestins during oocyte maturation in fish (Nagahama 1997, Thomas et al. 2002, Pace \& Thomas 2005). Activation of recombinant seatrout $\mathrm{mPR} \alpha$ in transfected human breast cancer cells (MDA-MB-231) by the known MIS of this species, 4-pregnen-17,20ß3,21-triol-3-one (20ß$\mathrm{S})$, causes stimulation of the mitogen-activated protein kinase (MAPK) cascade and inhibition of cAMP production through a pertussis toxin-sensitive, inhibitory $G$-protein $\left(G_{i}\right)$ pathway (Zhu et al. 2003a). These findings support the hypothesis that $\operatorname{mPR} \alpha$ acts as an intermediary in MIS induction of oocyte maturation in teleost fish. Recent results in human myometrial cells have shown that both $\mathrm{mPR} \alpha$ and $\mathrm{mPR} \beta$ are involved in downregulation of adenylyl cyclase activity through a pertussis toxin-sensitive $G_{i}$ pathway (Karteris et al. 2006). However, only $\operatorname{mPR} \alpha$ appears to mediate progesterone phosphorylation of the myosin light chain through activation of $\mathrm{p} 38 \mathrm{MAPK}$ and downregulate expression of the nuclear receptor co-activator, SRC2, in these myometrial cells (Karteris et al. 2006). Therefore, the role of $\operatorname{mPR} \beta$ in nongenomic signaling and its physiological functions still remain to be elucidated.

Zebrafish may be an excellent model to compare the functions and signaling mechanisms of different mPRs, since $\mathrm{mPR} \alpha$ and $\mathrm{mPR} \beta$ are co-expressed in the ovary and brain (Kazeto et al. 2005, Kohli et al. 2005). However, it is not known if $\mathrm{mPR} \beta$ can mediate similar signaling as the $\mathrm{mPR} \alpha$ in zebrafish and has similar functions. In this study, we examine the ability of various steroids to bind to the previously uncharacterized zebrafish $\mathrm{mPR} \alpha$ and $\operatorname{mPR} \beta$ receptors and rapidly activate the MAPK and cAMP pathways in stably transfected, nuclear progesterone receptor-deficient human cell lines. Our findings show that progestins bind to the $\operatorname{mPR} \alpha$ and $\operatorname{mPR} \beta$ specifically, and among the progestins tested, the MIS in zebrafish causes the greatest activation of MAPK and cAMP pathways through both $\operatorname{mPR} \alpha$ and $\operatorname{mPR} \beta$, suggesting these receptors have similar roles in mediating rapid progestin nongenomic actions.

\section{Materials and Methods}

\section{Plasmid constructs}

Zebrafish $\operatorname{mPR} \alpha$ and $\operatorname{mPR} \beta$ cDNAs, obtained previously (Zhu et al. 2003b), were inserted into mammalian expression vectors containing a CMV promoter and two C-terminal tags, V5 and His. The coding region of the $\mathrm{mPR} \alpha$ was amplified by PCR with primers for removal of the stop codon and containing BamHI and EcoRI enzyme-cutting sites for insertion into the mammalian expression vector pcDNA3.1/ $\mathrm{V} 5-\mathrm{His}$ A vector (Invitrogen). The primers used to amplify mPR $\alpha$ cDNA were 5'-AATGGATCCTCACCATGG-3' (forward) and 5'-CCACGACATGAATTCCTG-3' (reverse). The $\mathrm{mPR} \beta$-coding region was amplified with primers for removal of the stop codon and the CACC TOPO recognition site in the pcDNA TOPO vector (Invitrogen). The primers used to amplify mPR $\beta$ cDNA were $5^{\prime}$-CACCATGTCAAGTGGAGT-3' (forward) and $5^{\prime}$-TCAGTCTTTTTTCCTCACCTG-3' (reverse). The PCR products for both receptors were purified by electrophoresis on a $1 \%$ agarose gel, extracted with a gel prep kit (Qiagen), ligated with vector, and transformed into chemically competent Top 10 Escherichia coli cells following the manufacturer's instructions (Invitrogen). Transfected E. coli were spread on ampicillin-coated plates and grown overnight. Resistant colonies were then selected, regrown overnight, and the plasmid was purified by a MiniElute gel extraction kit (Qiagen). Constructs were verified for proper sequence by DNA sequencing using the BigDye terminator mix. The verified plasmid stocks were grown overnight and purified by alkaline lysis and PEG precipitation as described in Current Protocols in Molecular Biology (Ausubel et al. 2000). 


\section{Cell culture and transfection}

Human MDA-MB-231 breast carcinoma cells (American Type Culture Collection, Manassas, VA, USA) were used to express the recombinant $\operatorname{mPR} \alpha$ and $\operatorname{mPR} \beta$. The cells were cultured and maintained at $37^{\circ} \mathrm{C}$ with $5 \% \mathrm{CO}_{2}$ in Dulbeco's modified Eagle's medium/F-12 media without phenol red (Sigma) containing 10\% fetal bovine serum (Gibco). Media were changed every 2 days and cells were split among three plates when $90 \%$ confluent. Purified vector constructs of $\operatorname{mPR} \alpha$ and $\operatorname{mPR} \beta$ were then transfected into the cells using Lipofectamine reagent (Invitrogen) following the manufacturer's instructions. Two days after transfection, plasmidexpressing cells were selected using $1000 \mu \mathrm{g} / \mathrm{ml}$ G418 (Research Products International, Mt Prospect, IL, USA). Resistant colonies were then isolated and propagated with $500 \mu \mathrm{g} / \mathrm{ml} \mathrm{G} 418$ in order to produce stably transfected cell lines.

\section{Western blotting}

Expression of $\mathrm{mPR} \alpha$ and $\mathrm{mPR} \beta$ in the stably transfected cell lines was confirmed by Western blotting using a previously developed polyclonal antibody developed for the N-terminal of seatrout $\mathrm{mPR} \alpha(\mathrm{F} 1 \mathrm{~N} 2$; Zhu et al. 2003a), which crossreacts with both zebrafish $\operatorname{mPR} \alpha$ and $\operatorname{mPR} \beta$ cells. The corresponding $\mathrm{N}$-terminal region of zebrafish $\mathrm{mPR} \alpha$ (variable residues, VSDVPWVFRESHITGYRP) shares 84\% identity with the peptide antigen (VSDVPWVFRERHILTGYRQ) used for developing seatrout $\mathrm{mPR} \alpha$ N-terminal antibodies, whereas the corresponding $N$-terminal region of zebrafish $\mathrm{mPR} \beta$ (ASEVPSLFREPYILSGYRP) shares 58\% identity with the peptide. Samples were collected by scraping the cells at $4{ }^{\circ} \mathrm{C}$ into PBS containing $0 \cdot 1 \%$ protease inhibitor cocktail (Sigma). Ovary samples were collected by cervical dislocation followed by immediate removal and transfer of the ovary into PBS. Samples were sonicated with ten short bursts on a sonicator (Sonic Dismembrator, Fisher Scientific, Pittsburgh, PA, USA), the homogenate was centrifuged for $10 \mathrm{~min}$ at $20000 \boldsymbol{g}$, and the resulting pellets were resuspended in lysis buffer containing $150 \mathrm{mM} \mathrm{NaCl}, 10 \mathrm{mM}$ Tris- $\mathrm{HCl}(\mathrm{pH}$ 7.4), 1\% NP-40 (Calbiochem, San Diego, CA, USA), and $0 \cdot 1 \%$ protease inhibitor cocktail (Sigma), and incubated for $30 \mathrm{~min}$ at $4{ }^{\circ} \mathrm{C}$ in order to solubilize membrane proteins. Samples were then spun for $10 \mathrm{~min}$ at $20000 \mathrm{~g}$ to remove undissolved material. The remaining supernatant was mixed with equal amounts of $2 \times \mathrm{SDS}$ sample buffer $(0 \cdot 125 \mathrm{M}$ Tris- $\mathrm{HCl} \quad(\mathrm{pH} \quad 6 \cdot 8), \quad 4 \%$ SDS, $20 \%$ glycerol, $10 \%$ 2-mercaptoethanol), boiled for $5 \mathrm{~min}$ and then cooled on ice.

For western-blot analysis, $20 \mu \mathrm{g}$ (MAPK assays) and $50 \mu \mathrm{g}$ (mPR expression assays) total protein estimated by the Bradford assay (Bio-Rad), were loaded onto a SDS/12\% PAGE gel and transferred to a nitrocellulose membrane. The membrane was blocked with $5 \%$ nonfat milk in TBST (50 mM Tris, $100 \mathrm{mM} \mathrm{NaCl,} \mathrm{0 \cdot 1 \%} \mathrm{Tween} 20(\mathrm{pH} \mathrm{7 \cdot 4))} \mathrm{for}$
$1 \mathrm{~h}$. The membrane was further incubated with the mPR antibody (1:5000 dilution) or extracellular signal-related kinase (ERK) and phosphorylated ERK antibodies overnight (Cell Signaling, Beverly, MA, USA), followed by four 5-min TBST washes, incubated for $1 \mathrm{~h}$ with horseradish peroxidase conjugated to goat anti-rabbit antibody (1:2000 dilution; Cell Signaling), and finally washed three times for $5 \mathrm{~min}$ with TBST. The blots were then developed using Super Signal West Extended Dura Substrate (Pierce, Rockford, IL, USA) and visualized using a Fluor Chem 8900 imaging station (Alpha Innotech, San Leandro, CA, USA).

\section{Cell surface biotinylation and pull-down assay}

Surface expression of the receptor was also verified by biotin labeling of surface proteins with EZ-Link Sulfo-NHSLC-Biotin (Pierce), followed by immunoprecipitation with immobilized streptavidin (Pierce) and western blotting with the seatrout $\mathrm{mPR} \alpha$-specific antibody. Cells were grown for at least $48 \mathrm{~h}$ until they were $90 \%$ confluent in $25 \mathrm{~cm}^{2}$ cell culture-treated flasks and then washed three times with PBS (pH 8). The cells were then incubated with $1 \mathrm{mg} / \mathrm{ml}$ sulfoNHS-LC biotin (Pierce) for $30 \mathrm{~min}$ at $4{ }^{\circ} \mathrm{C}$. The reaction was quenched by washing the cells twice with $10 \mathrm{ml}$ ice-cold PBS containing $50 \mathrm{mM}$ Tris- $\mathrm{HCl}(\mathrm{pH} \mathrm{7 \cdot 5)}$. Cell samples were removed by the addition of lysis buffer containing $150 \mathrm{mM}$ $\mathrm{NaCl}, 10 \mathrm{mM}$ Tris-HCl (pH 7·5), 1\% NP-40 (Calbiochem), and $0 \cdot 1 \%$ protease inhibitor cocktail (Sigma) directly to the plates. The samples were solubilized for $30 \mathrm{~min}$ at $4{ }^{\circ} \mathrm{C}$ with shaking and then centrifuged for $10 \mathrm{~min}$ at $20000 \mathrm{~g}$ to remove undissolved material. The biotinylated proteins were purified by incubating supernatants with $200 \mu \mathrm{l}$ immobilized strepavidin-agarose slurry (Pierce) at $4{ }^{\circ} \mathrm{C}$ overnight with continuous mixing. Beads were then washed three times with $1 \mathrm{ml} 0 \cdot 1 \%$ wash buffer containing $0 \cdot 1 \% \mathrm{NP} 40,150 \mathrm{mM}$ $\mathrm{NaCl}$, and $20 \mathrm{mM}$ Tris- $\mathrm{HCl}(\mathrm{pH} 7 \cdot 5)$, and then biotinylated proteins were eluted by incubating the slurry for $1 \mathrm{~h}$ at $55^{\circ} \mathrm{C}$ in $100 \mu \mathrm{l} 2 \times \mathrm{SDS}$ sample buffer. Final samples were spun down, extracted from the resin and then analyzed by western blotting as described previously.

\section{Flow cytometry}

Expression of the receptors was further verified by flow cytometry using a fluorescein-5-isothiocyanate (FITC)conjugated V5 antibody (Invitrogen) or His (Cell Signaling) and mPR primary antibody with a FITC-conjugated antirabbit secondary antibody (Jackson ImmunoResearch, West Grove, PA, USA). Approximately $1 \times 10^{6}$ cells were collected by scraping into $2 \mathrm{ml}$ PBS and then spun down at 1350 r.p.m. for all the washing steps. The cells were decanted, permeabilized for $15 \mathrm{~min}$ on ice with $90 \%$ methanol for staining with V5 and His antibodies, or left on ice for $\mathrm{mPR}$ antibody staining. Following two washes in PBS, the harvested cells were washed with blocking solution consisting of $0 \cdot 5 \%$ BSA in PBS. The cells were then incubated with unlabeled 
primary antibodies (His or mPR, 1:200 dilution in blocking solution) or FITC-conjugated V5 antibodies for $30 \mathrm{~min}$ at $4{ }^{\circ} \mathrm{C}$ in the dark. Those cells that reacted with the unlabeled primary antibodies were further incubated with FITCconjugated anti-rabbit antibodies (1:500 dilution) following two washes with blocking solution. These samples were resuspended in $100 \mu \mathrm{l}$ PBS for analysis on the flow cytometer following two washes in blocking solution. Analysis of 10000 events was performed on a FACScan flow cytometer using CELLQest software (BD Biosciences, Palo Alto, CA, USA). For expression analysis, a gate (a minimum fluorescence intensity) was set above $95 \%$ of the untransfected control cell population. The percentage of recombinant cells expressing fluorescence intensity above the gate was reported after subtracting $5 \%$ from the total.

\section{Receptor-binding assays}

$\left[1,2,6,7{ }^{3} \mathrm{H}\right] 17 \alpha$-Hydroxyprogesterone $(85 \mathrm{Ci} / \mathrm{mmol})$ was purchased from New England Nuclear (Boston, MA, USA) and enzymatically converted to 4-pregnen-17,20 $\beta$-diol-3one (17,20 $\beta-\mathrm{DHP})$ as described previously (Scott et al. 1982). Plasma membrane fractions of MDA-MB-231 cells were obtained following established procedures with few modifications (Patiño and Thomas 1990b, Zhu et al. 2003a). The cells were washed with assay buffer and then sonicated for $15 \mathrm{~s}$, followed by a $1000 \mathrm{~g}$ centrifugation for $7 \mathrm{~min}$ to remove any nuclear and heavy mitochondrial material. The resulting supernatant was centrifuged at $20000 \boldsymbol{g}$ for $20 \mathrm{~min}$ to obtain the plasma membrane fraction. Progestin receptor binding in the membrane fractions was characterized as described previously (Patiño \& Thomas 1990b). One set of tubes contained radiolabeled 17,20 $\beta$-DHP alone (total binding), another set also contained cold progestin competitor at a 1000 fold greater concentration to measure nonspecific binding. For competition assays, a third set of tubes contained radiolabeled steroids and various concentrations of the steroid competitors ranging from $100 \mathrm{pM}-10 \mu \mathrm{M}$ (dissolved in 1-5 $\mu$ l ethanol $(\mathrm{EtOH})$ ), which do not affect ligand binding in the receptor assay. After a $30-\mathrm{min}$ incubation at $4{ }^{\circ} \mathrm{C}$ with the membrane fractions, the reaction was stopped by filtration (Whatman GF/ B filters, presoaked in assay buffer; Fisher Scientific, Pittsburgh, PA, USA). The filters were washed twice with $25 \mathrm{ml}$ assay buffer and the bound radioactivity was measured by scintillation counting. The displacement of the radiolabeled $17,20 \beta$-DHP binding by the steroid competitors was expressed as a percentage of the maximum specific binding of the 17,20 $\beta$-DHP for the mPRs.

\section{Immunofluorescence staining of $m P R$ in zebrafish oocytes}

Oocytes were collected from adult zebrafish, separated by size, fixed in Bouin's fixative (70\% v/v Picric acid, $23 \% \mathrm{v} / \mathrm{v}$ of $40 \%$ aqueous formaldehyde, and $4 \cdot 7 \% \mathrm{v} / \mathrm{v}$ glacial acetic acid) for $24 \mathrm{~h}$ at $4{ }^{\circ} \mathrm{C}$ and stored in $100 \%$ methanol at $-20^{\circ} \mathrm{C}$ until processed for immunohistochemistry. Oocytes were then dehydrated for $5 \mathrm{~min}$ with 75, 90, 100\% EtOH, 100\% xylene, and then mounted in paraffin wax cassettes. Paraffin sections were cut at $6 \mu \mathrm{m}$ and placed on Superfrost glass slides (Fisher Scientific). The oocyte sections were then deparaffinized by 5-min washes with 100\% xylene twice, 100, 95, 70\% EtOH, and twice with PBS.

Blocking was carried out at room temperature for $1 \mathrm{~h}$ in PBS containing $2 \%$ BSA and $1 \%$ goat normal serum. The slides were then incubated overnight at $4{ }^{\circ} \mathrm{C}$ with $\mathrm{mPR}$ antibody (1:400 dilution) in PBS containing $2 \%$ BSA, washed three times with PBS and then incubated for $2 \mathrm{~h}$ at room temperature with FITC-conjugated goat anti-rabbit antibody (Jackson ImmunoResearch; 1:500 dilution) in PBS with 2\% BSA and $1 \%$ goat normal serum. The slides were then washed three times with PBS, treated with $70 \% \mathrm{EtOH}$ for $5 \mathrm{~min}$, equilibrated with PBS, and then mounted using an antifade reagent (1\% 1,4-diazabicyclo[2,2,2]octane; Sigma), in 90\% glyceraldehyde, phosphate buffered) and observed under a fluorescence microscope (Olympus BX-40 fluorescence microscope).

\section{$M A P K$ activation and ligand screening}

MAPK activation was measured by both western blotting and flow cytometry using a phospho-specific p44/p42 antibody (1:2000 dilution for western-blots and 1:200 dilution for flow cytometry; Cell Signaling). Cells were split at least $48 \mathrm{~h}$ prior to testing to allow $\mathrm{mPR}$ protein expression to recover and then serum starved for $72 \mathrm{~h}$ to reduce basal MAPK activity. Activation was measured after 5-min exposure to various steroids (Steraloids, Newport, RI, USA) added directly to the media. Steroids were dissolved in $\mathrm{EtOH}$, so an equivalent amount of EtOH was added in the control group. Epidermal growth factor was used as a positive control of activation. Cells were then either immediately lysed in $1 \times$ SDS sample buffer for western analysis or fixed with $2 \%$ paraformaldehyde dissolved in PBS for 10 min for flow cytometry analysis, both using the same phospho-specific p44/p42 antibody. Following western blotting with phospho-specific antibody, the membrane blots were stripped for $30 \mathrm{~min}$ at $50{ }^{\circ} \mathrm{C}$ in stripping buffer (2\% SDS, $62.5 \mathrm{mM}$ Tris (pH 6.8), $100 \mathrm{mM}$ $\beta$-mercaptoethanol) and washed five times in TBST. Then, the membrane blots were reblotted with total MAPK antibody in order to confirm equal protein loading. For MAPK flow cytometry analysis, the following modifications were made to the flow cytometry methods described previously. The cells were washed two more times with PBS before scraping from the plate. Then, the cells were permeabilized and incubated with the phospho-specific MAPK primary antibody (1:250), and a FITC-conjugated goat anti-rabbit secondary antibody (1:500 dilution; Jackson ImmunoResearch).

\section{cAMP measurements}

The levels of cAMP in transfected cells were measured using a nonradioactive enzyme immunoassay kit (Cayman Chemical, Ann Arbor, MI, USA). Cells were prepared by splitting at least $48 \mathrm{~h}$ prior to testing to allow $\mathrm{mPR}$ protein expression to 
recover and then serum starved for $18 \mathrm{~h}$ to reduce the background levels of steroids in the media. For pertussis toxin pretreatment, cells were incubated overnight with $200 \mathrm{ng} / \mathrm{ml}$ pertussis toxin added to the serum-free media. For cholera toxin treatment, cells were incubated with $1 \mu \mathrm{g} / \mathrm{ml}$ cholera toxin $2 \mathrm{~h}$ before treatment. Cells were then stimulated with $1 \mu \mathrm{M}$ forskolin for $15 \mathrm{~min}$ followed by steroid treatment for $15 \mathrm{~min}$. Samples were then placed on ice, the media removed, $66 \% \mathrm{EtOH}$ added, and then samples were immediately frozen at $-80{ }^{\circ} \mathrm{C}$. Samples were thawed and cAMP was measured in aliquots of supernatant according to the manufacturer's instructions. Data were analyzed by a spreadsheet program provided by Cayman Chemical, which calculated cAMP content in picomoles per milliliter. For each sample, the amount of protein was measured by the Bradford assay and then standardized to express the final value as picomoles cAMP per microgram protein.

\section{Statistical analysis}

All experiments were repeated at least three times. Westernblots were analyzed for fluorescent intensity by Alpha Innotech analysis software and expressed as the mean-fold change (MFC) in band intensity \pm s.E.M. Data were analyzed using the GraphPad Prism Program (San Diego, CA, USA) to calculate a one-way ANOVA. A Newman-Keuls multiple comparison test was used to determine specific differences between means when determined as significant by ANOVA. A $P$ value $<0 \cdot 05$ was considered statistically significant.

\section{Results}

Western-blot analysis of zebrafish ovarian membrane proteins using the seatrout $\operatorname{mPR} \alpha$ antibody showed a single immunoreactive band at $\sim 40 \mathrm{kDa}$ (Fig. 1). The membrane localization of the receptor in zebrafish oocytes was further confirmed by immunohistochemistry using the same $\mathrm{mPR} \alpha$ antibody (Fig. 2), in agreement with previous results showing membrane localization of the mPR $\alpha$ in spotted seatrout oocytes.

In order to examine the signaling pathways activated through the zebrafish $\mathrm{mPR} \alpha$ and $\mathrm{mPR} \beta$, the receptors were stably expressed in a human breast cancer cell line not responsive to progestins, MDA-MB-231 cells. The cell line has no nuclear progesterone receptor (Horwitz et al. 1978) or rapid progestin response (see supplementary data in the online version of Journal of Endocrinology at http://joe.endocrinology-journals.org/ content/vol190/issue2/), therefore, any response induced in the transfected cells can be directly related to the presence of the recombinant $\mathrm{mPR} s$ and independent of the nuclear progestin receptor. The membrane expression of $\operatorname{mPR} \alpha$ and $\operatorname{mPR} \beta$ was first verified by western blotting of $50 \mu \mathrm{g}$ total protein extracted from cell membranes (Fig. 1A). A distinct band at $\sim 45 \mathrm{kDa}$ was present in the membrane proteins extracted from $\operatorname{mPR} \alpha$ - or $\mathrm{mPR} \beta$-transfected cell lines, whereas the band was absent in the nontransfected control cells (Fig. 1A). The slightly higher molecular mass $(45 \mathrm{kDa})$ of recombinant $\mathrm{mPR} \alpha$ or $\operatorname{mPR} \beta$
A Unlabeled B Biotin labeled

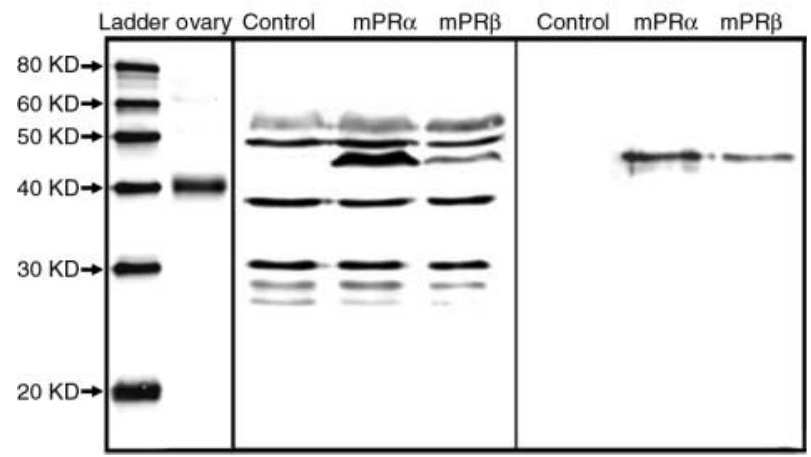

Figure 1 Western-blot analysis of zebrafish ovary and transfected membrane progestin receptor $(\mathrm{mPR} \alpha$ and $\mathrm{mPR} \beta)$ cells using antibody against seatrout $\mathrm{mPR} \alpha$. A unique band at $40 \mathrm{kDa}$ was seen for the ovarian membrane sample corresponding to the $\mathrm{mPR}$ protein and bands at $45 \mathrm{kDa}$ corresponding to the recombinant $\mathrm{mPR} \alpha$ and $\mathrm{mPR} \beta$ receptors from $50 \mu \mathrm{g}$ total proteins $(\mathrm{A})$ extracted from zebrafish ovarian membrane or MDA-MB-231 cell membranes respectively, and plasma membrane proteins (B) following biotinsurface labeling and immunoprecipitation of cell-surface proteins.

compared with the native protein expressed in the zebrafish ovary was due to the added tags that had approximately $5 \mathrm{kDa}$. The cell surface localization of the receptor was further confirmed by biotinylation and a streptavidin pull-down assay. Only one unique $45 \mathrm{kDa}$ band corresponding to the recombinant molecular size of tagged $\operatorname{mPR} \alpha$ and $\operatorname{mPR} \beta$ was observed in the streptavidin-immunoprecipitated plasma membrane proteins using the seatrout $\operatorname{mPR} \alpha$ antibody (Fig. 1B). These results indicate that the recombinant receptors are localized on the surface of the cell (Fig. 1B), which is consistent with the cell-surface expression of the wild-type mPR proteins in the zebrafish oocytes (Fig. 2). To further verify receptor expression in transfected cells, flow cytometry was used to measure the presence of C-terminal receptor tag impermeabilized cells with fluorescently linked V5 or His antibodies, or the N-terminal of the receptor with the mPR antibody in nonpermeabilized cells (Fig. 3). Repeated measurements with each antibody showed at least 16-24\% of the $\mathrm{mPR} \alpha$-transfected cells expressed the receptor and at least 54-64\% of the cells transfected with $\mathrm{mPR} \beta$-expressed $\mathrm{mPR} \beta$ (Fig. 3). Significant staining with the $\mathrm{N}$-terminal $\mathrm{mPR}$ antibody in nonpermeabilized cells also implies surface expression of the receptors. Low levels of receptor expression in the stable cell lines may account for less than $100 \%$ measured expression by flow cytometry.

Specific progestin binding was measured in plasma membranes prepared from $\mathrm{mPR} \alpha$ - and $\mathrm{mPR} \beta$-transfected cells, whereas significantly lower amounts of progestin binding were detected in nontransfected cell membranes (Fig. 4). Saturation analysis showed progestin binding to the cell membranes of transfected cells is saturable and of limited capacity $\left(\mathrm{mPR} \alpha, B_{\max }=0.04 \mathrm{nM} ; \mathrm{mPR} \beta, B_{\max }=0.07 \mathrm{nM}\right.$; Fig. 5). Scatchard analysis showed the presence of a single class of high-affinity-binding sites ( $\mathrm{mPR} \alpha$, $K_{\mathrm{d}}=7 \mathrm{nM} ; \operatorname{mPR} \beta, K_{\mathrm{d}}=12 \mathrm{nM} ;$ Fig. 5) in the cell 

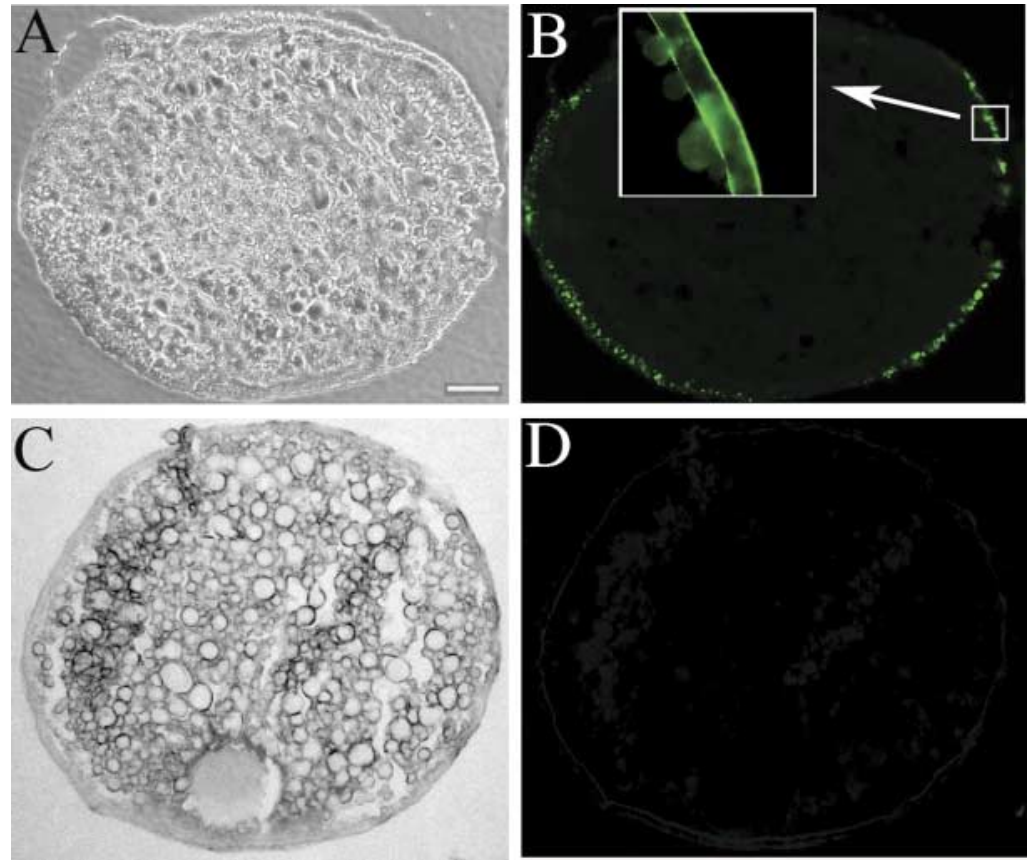

Figure 2 Immunofluorescent localization of $\mathrm{mPR}$ in zebrafish oocytes. (A) An oocyte reacted with $\mathrm{mPR}$ antibody under normal light. (B) Positive fluorescence reaction (GFP) was observed on the ovarian membrane of the same oocyte under GFP fluorescent light. Insert, mPR was observed on the oocyte membrane at a high magnification. (C) An oocyte reacted with secondary antibody only under normal light. (D) No GFP was observed in the same oocyte under GFP fluorescent light. Bar $=100 \mu \mathrm{m}$.

HIS
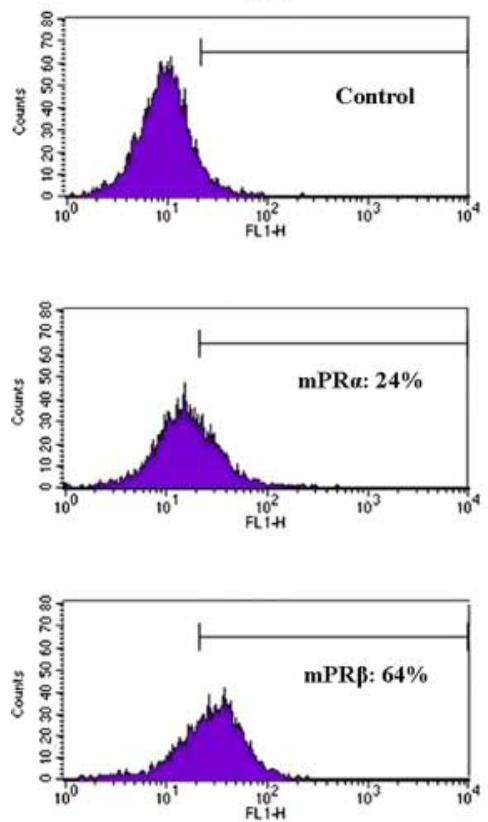

V5
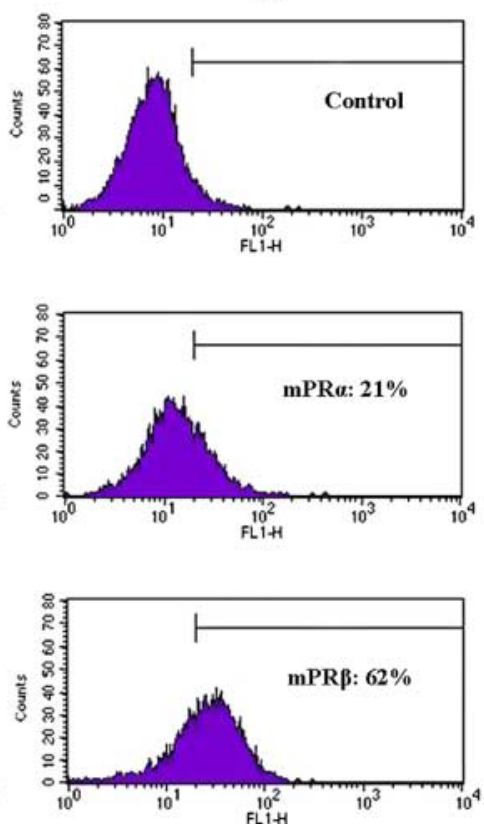

mPR
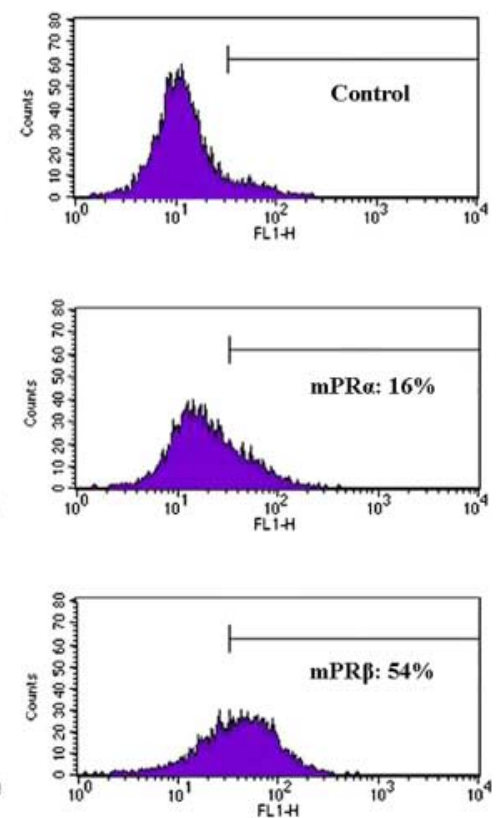

Figure 3 Flow cytometry analysis of $m P R \alpha$ and $m P R \beta$ in stably transfected cells using His or mPR primary antibody with FITC-conjugated secondary antibody or FITC-conjugated V5 antibody. Cells were permeabilized for His and V5 staining of C-terminal receptor tag and nonpermeabilized for staining with the $\mathrm{N}$-terminal mPR antibody. Results, expressed as percentage of mPR $\alpha$ - and mPR $\beta$-transfected cells, show greater fluorescent intensity than a gated control population. Horizontal bar in the figure represents a gate set above $95 \%$ of the untransfected control population. The number in the figure indicates the percentage of recombinant cells under the gate after $5 \%$ were subtracted. 


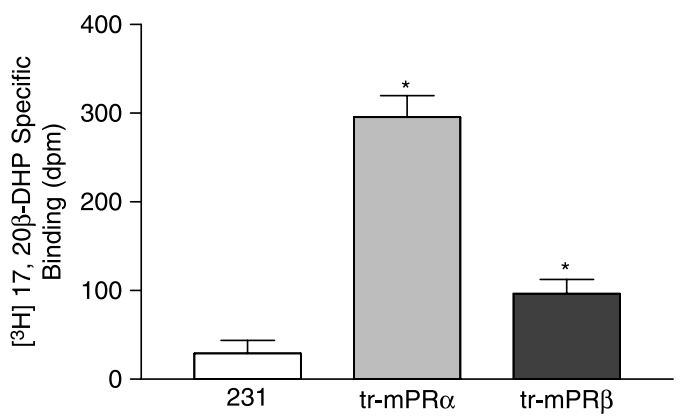

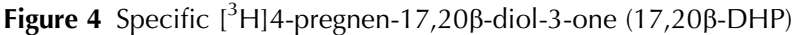
binding assessed by a single point radioreceptor assay (total binding tubes: $4 \mathrm{nM}\left[{ }^{3} \mathrm{H}\right] 17,20 \beta$-DHP, nonspecific-binding tubes: $+4 \mu \mathrm{M}$ $17,20 \beta-D H P)$ to the plasma membranes of nontransfected MBAMD-231 cells (231), zebrafish $\mathrm{mPR} \alpha$-transfected (tr-mPR $\alpha$ ) or zebrafish mPR $\beta$-transfected (tr-mPR $\beta$ ) cells. ${ }^{*} P<0 \cdot 05$ compared with controls. Values are means \pm S.E.M. from three independent assays with different batches of cells.
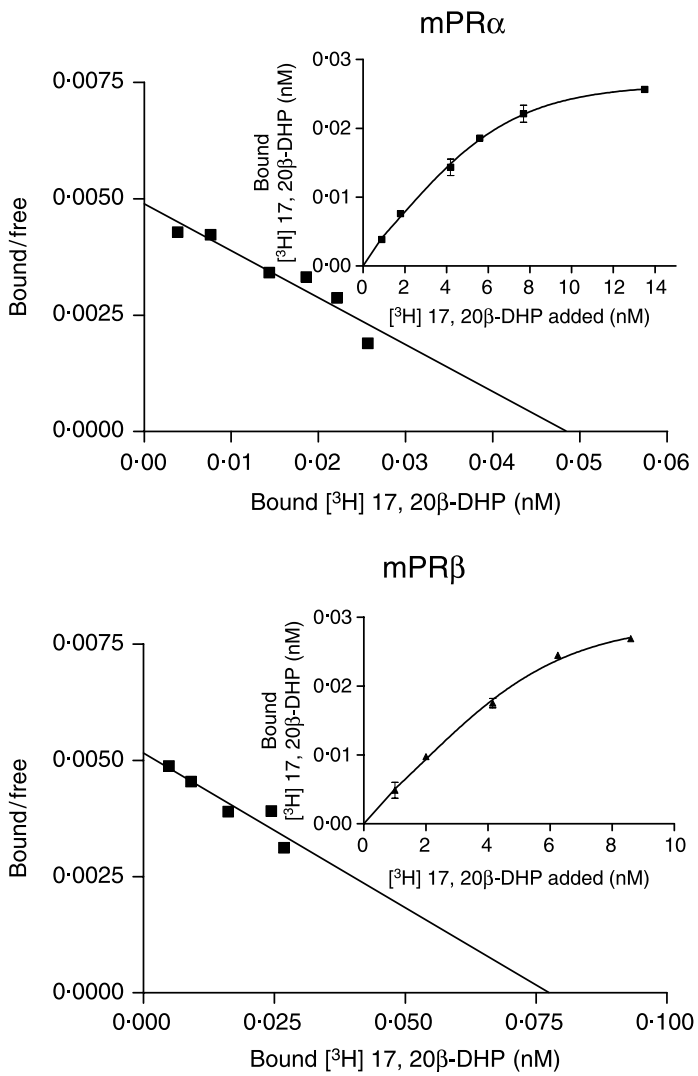

Figure 5 Saturation analyses and Scatchard plots of specific $\left[{ }^{3} \mathrm{H}\right] 4$-pregnen-17,20ß-diol-3-one $(17,20 \beta$-DHP) binding to the plasma membranes of $\mathrm{mPR} \alpha$ - and mPR $\beta$-transfected cells.

Representative plots are shown. Nearly identical results were obtained in three independent assays with different batches of cells.
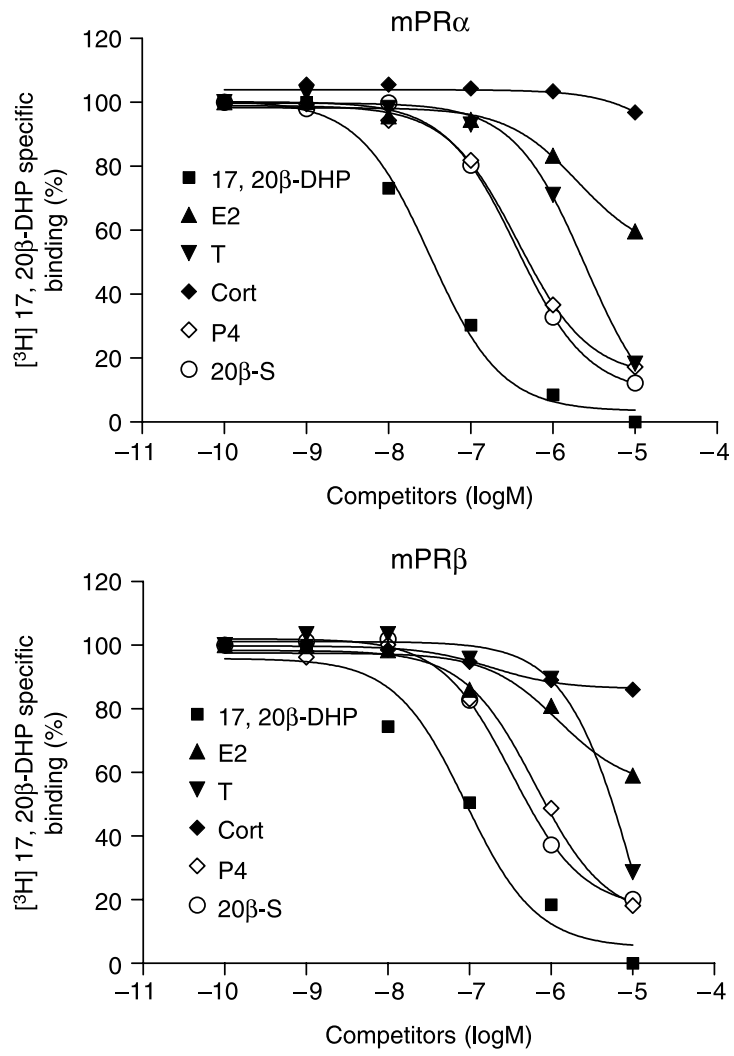

Figure 6 Competition curves of steroid binding expressed as a percentage of maximum specific $\left[{ }^{3} \mathrm{H}\right] 4$-pregnen-17,20 $\beta$-diol-3one $(17,20 \beta-\mathrm{DHP})$ binding to plasma membranes prepared from mPR $\alpha$ - and mPR $\beta$-transfected cells $\left(\left[{ }^{3} \mathrm{H}\right] 17,20 \beta\right.$-DHP: $\left.4 \mathrm{nM}\right)$. $17,20 \beta-\mathrm{DHP} ; \diamond$, progesterone; $\bigcirc, 20 \beta-S ; \boldsymbol{\nabla}$, testosterone; $\boldsymbol{\Delta}$, estradiol-17 $\beta$; , cortisol. Values are means from three independent assays with different batches of cells.

membranes. Steroid competition studies showed that binding is highly specific for $17,20 \beta-\mathrm{DHP}$ in membranes prepared from both $\mathrm{mPR} \alpha$ - and $\mathrm{mPR} \beta$-transfected cells (Fig. 6). The relative binding affinities of steroids to the recombinant $\mathrm{mPR} \alpha$ and $\mathrm{mPR} \beta$ were very similar. Progesterone (P4) and $20 \beta-S$ have binding affinities approximately $10 \%$ that of $17,20 \beta-$ DHP, whereas testosterone and estradiol- $17 \beta$ only displaced $\left[{ }^{3} \mathrm{H}\right] 17,20 \beta-$ DHP binding from the receptors at 100-fold higher concentrations, and cortisol showed no displacement at any of the concentrations tested (Fig. 6).

The degree of MAPK activation in the transfected cell lines through the mPRs in response to various steroids, including

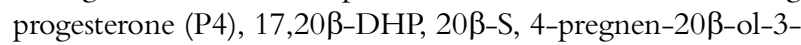
one (20 $\beta$-hydroxyprogesterone, 20HP), 4-pregnen-17-ol3,20-dione (17-hydroxyprogesterone, 17HP), cortisol (Cort), 11-desoxycortisol (11DC), testosterone (Test), and estrogen (E2), was measured. Two independent methods - flow cytometry and western blotting - were used to measure the amount of MAPK activation by means of a phospho-specific MAPK antibody. Western blotting showed a significant increase $(P<0 \cdot 05)$ MAPK activation in mPR-transfected cells after only 
5 min of stimulation with $1 \mu \mathrm{M}$ P 4 along with the known MISs

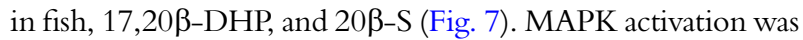
expressed as an average MFC in western-blot band intensity in active p-ERK over untreated samples. Interestingly, the known zebrafish MIS, 17,20 $\beta$-DHP, was the most significant $(P<0 \cdot 05)$ steroid activator of MAPK in both $\mathrm{mPR} \alpha-(3 \cdot 48 \pm 0 \cdot 26$ MFC)- and mPR $\beta-(3 \cdot 62 \pm 0 \cdot 18$ MFC) transfected lines. Although testosterone $(\mathrm{mPR} \alpha, 2 \cdot 55 \pm 0 \cdot 34 \mathrm{MFC} ; \mathrm{mPR} \beta$, $2 \cdot 40 \pm 0 \cdot 31 \mathrm{MFC})$ also caused lower, but significant $(P<0 \cdot 05)$ MAPK activation in the transfected cell lines, this effect was also
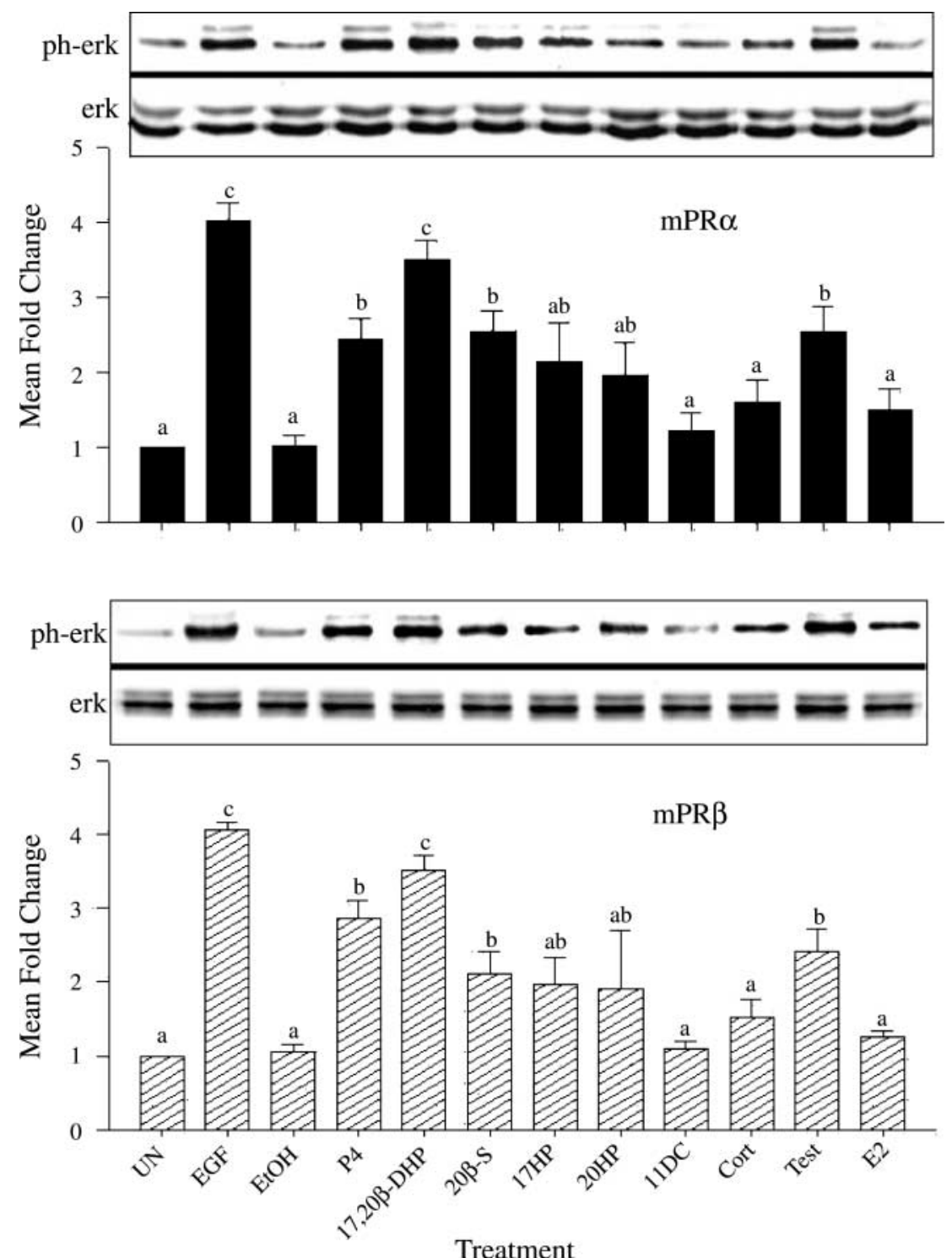

Figure 7 MAPK pathway activation in $\mathrm{mPR} \alpha$-and $\mathrm{mPR} \beta$-transfected cells after 5 min stimulation with

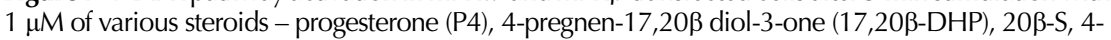
pregnen-20 $\beta$-ol-3-one (20HP), 4-pregnen-17-ol-3,20-dione (17HP), cortisol (Cort), 11-desoxycortisol (11DC), testosterone (Test), and estradiol-17 $\beta$ (E2). Representative western-blots for active phosphorylated p-ERK and total ERK (top). Mean-fold change (MFC) in active p-ERK over untreated samples, expressed as the mean \pm s.E.M. for at least four separate experiments (bottom). P4 as well as the fish maturation-inducing progestins, 17,20 $\beta$-DHP and 20 $\beta$-S, show significant MAPK activation over control treatments. 17,20 $\beta$-DHP showed the most significant activation of the steroids tested. Epidermal growth factor (EGF) was used as a positive control of MAPK activation and the vehicle for steroid delivery, EtOH, was used as a negative control. Bars (mean \pm s.E.M.) with different letters are significantly different from one another $(P<0 \cdot 05)$. UN, untreated control. 

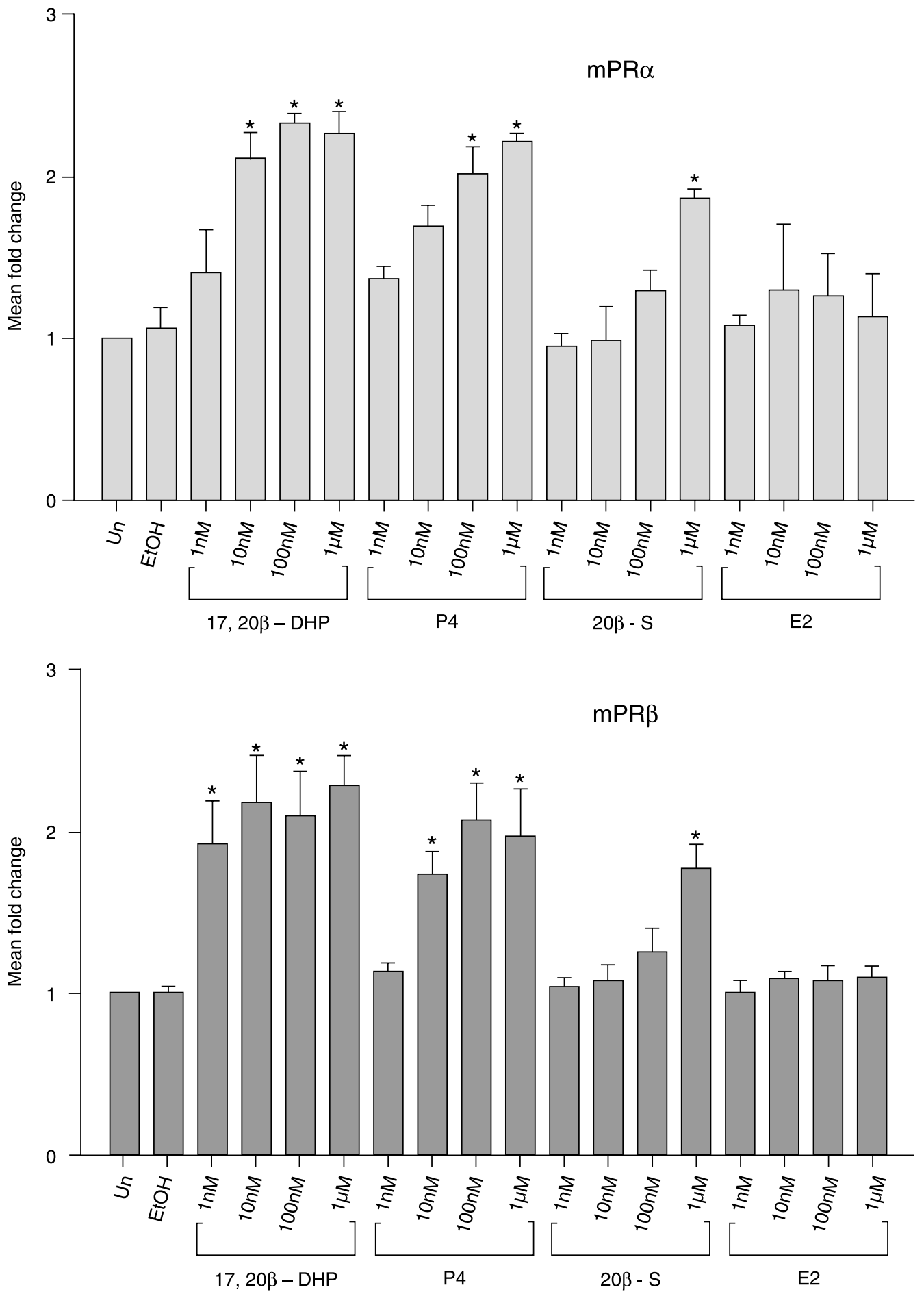

Figure 8 MAPK activation in $\mathrm{mPR} \alpha$ - and $\mathrm{mPR} \beta$-transfected cells after 5 min stimulation with various steroids at various concentrations (1 $\mathrm{nM}-1 \mu \mathrm{M})$ - progesterone (P4), 4-pregnen-17,20 $\beta$-diol-3-one (17,20 $\beta$-DHP), 4-

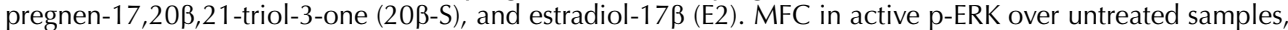
expressed as an average \pm S.E.M. for at least four separate experiments $\left({ }^{*} P<0 \cdot 05\right)$. Un, untreated control. 
seen in the control cells $(1 \cdot 85 \pm 0 \cdot 23 \mathrm{MFC})$, implying that the response was not specific for the transfected receptors (see Fig. 1 in Supplementary data). Furthermore, the degree of MAPK activation in response to P4, 17,20 $\beta$-DHP, and $20 \beta-S$ was dose dependent (Fig. 8). Significant MAPK activation in $\mathrm{mPR} \alpha-$ transfected cells was observed after treatment with $17 \alpha, 20 \beta$ DHP or P4 at a concentration of 10 and $100 \mathrm{nM}$ respectively, whereas, tenfold lower concentrations of 17,20 $\beta$-DHP (1 nM) or P4 (10 nM) were able to elicit significant MAPK activation in mPR $\beta$-transfected cells. Significant activation by $20 \beta-S$ was observed in $\mathrm{mPR} \alpha$ - and $\mathrm{mPR} \beta$-transfected cells only at $1 \mu \mathrm{M}$ concentrations.

A second method, flow cytometry, was used in order to verify progestin induction of MAPK activity in the transfected cells. An increase in median fluorescent intensity (MFI; median fluorescent intensity of treated/median fluorescent intensity of untreated) corresponding to the amount of MAPK activation was observed in both $\mathrm{mPR} \alpha-$ and $\mathrm{mPR} \beta$-transfected cells in response to $1 \mu \mathrm{M} \mathrm{P} 4$ and 17,20 $\beta$-DHP activation for $5 \mathrm{~min}$ (Fig. 9). Once again, the zebrafish MIS, 17,20 $\beta$-DHP showed consistently higher amounts of MAPK induction than the other progestins in both the $\operatorname{mPR} \alpha$ and $\operatorname{mPR} \beta$ cell lines.

The effect of various steroids on cAMP concentrations, a measure of adenylyl cyclase activity, in the transfected cell lines was also investigated. Cells were first pretreated for
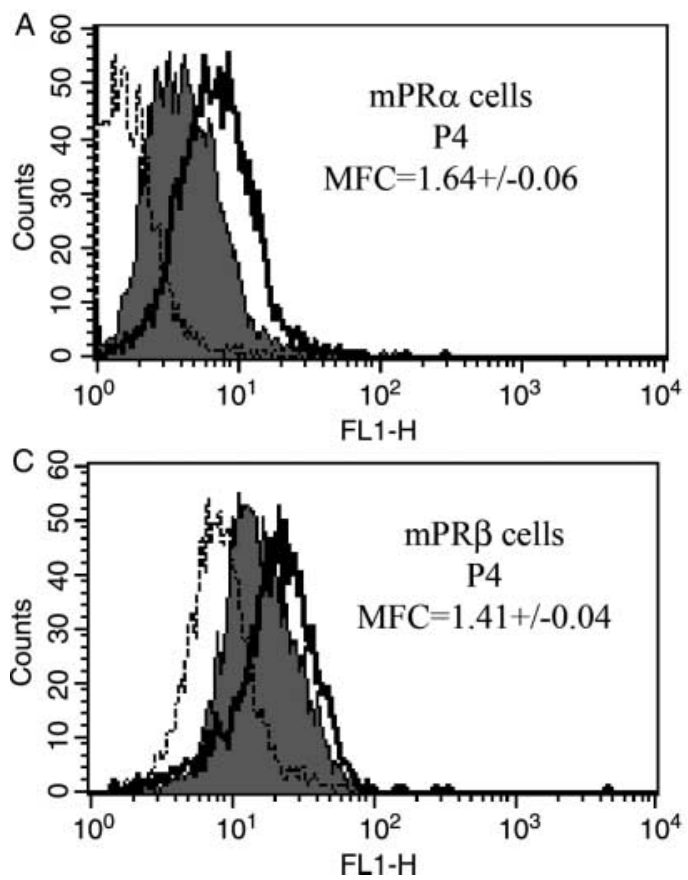

Figure 9 MAPK activation in $\mathrm{mPR} \alpha$ - and $\mathrm{mPR} \beta$-transfected cells after 5 min stimulation with $1 \mu \mathrm{M}$ progestins (solid line) compared with untreated mPR-transfected cells (solid filled line) and negative control of secondary antibody only (dotted line) as detected by flow cytometry. The mPR $\alpha$-transfected cells showed a $1.64 \pm 0.06 \mathrm{MFI}$ for progesterone

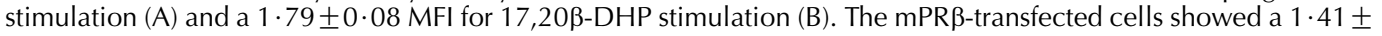

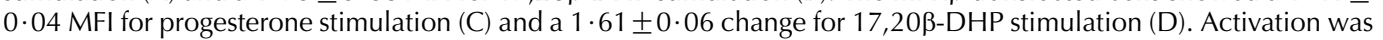
measured for 10000 cells (MFI; median fluorescent intensity of treated/median fluorescent intensity of untreated, mean $\mathrm{MFI} \pm$ S.E.M., $n=3$ ). 

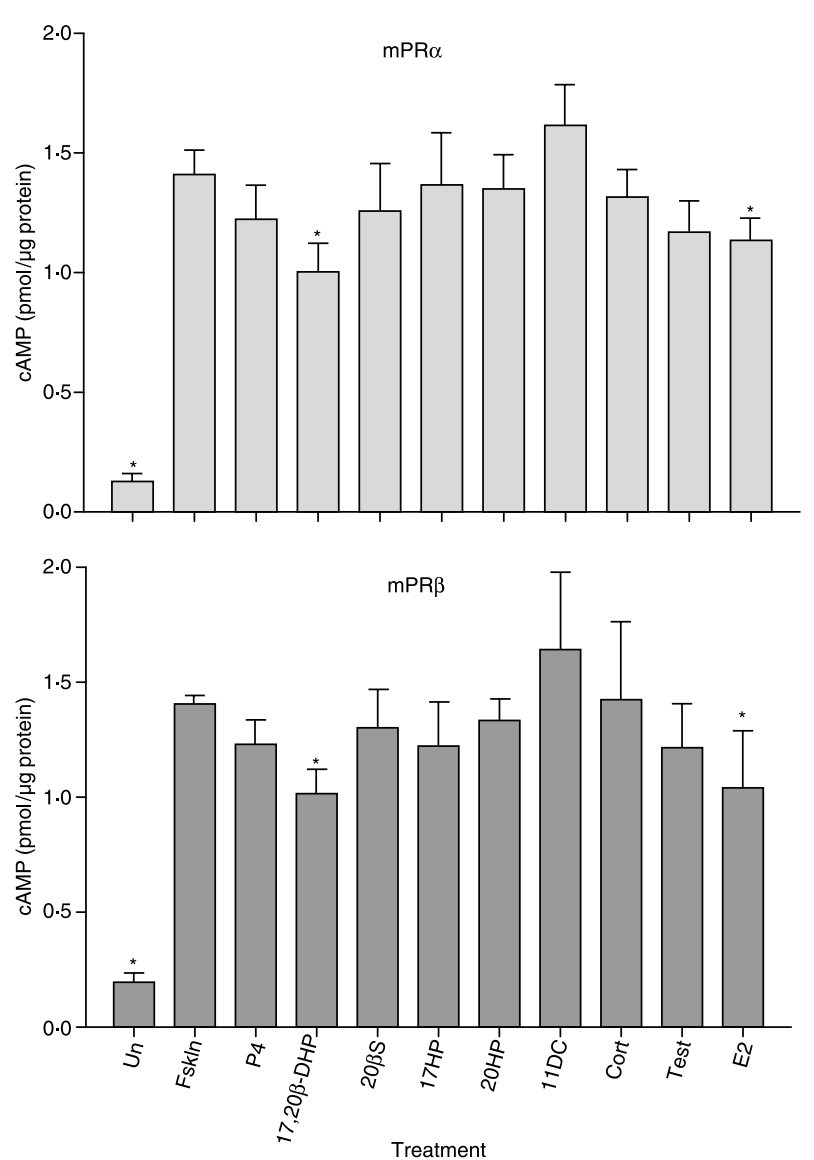

Figure 10 cAMP levels in $\mathrm{mPR} \alpha$ - and $\mathrm{mPR} \beta$-transfected cells after 15 min stimulation with $1 \mu \mathrm{M}$ various steroids - progesterone (P4), 4pregnene-17 $\alpha, 20 \beta$ diol-3-one $(17,20 \beta$-DHP), 4-pregnen-17,20 3,21 triol-3-one (20ß-S), 4-pregnen-20ß-ol-3-one (20HP), 4-pregnen17-ol-3,20-dione (17HP), cortisol (Cort), 11-desoxycortisol (11DC), testosterone (Test), and estrogen (E2). Samples were pretreated with $1 \mu \mathrm{M}$ forskolin (Fskln) for 15 min prior to the addition of steroid (mean \pm S.E.M., $n=6,{ }^{*} P<0 \cdot 05$ ). Un, untreated control.

implying $G_{i}$ coupling of the receptor (Fig. 13). However, pertussis toxin caused no inhibition of $\mathrm{mPR} \beta$-mediated reduction of cAMP levels, implying possible coupling to a different member of the G-protein superfamily (Fields \& Casey 1997). In order to examine the possibility that $m P R \beta$ is a $G_{s}$ coupled receptor, the experiments were repeated in the presence of $1 \mu \mathrm{g} / \mathrm{ml}$ cholera toxin, a $G_{\mathrm{s}}$ activation enhancer. Cholera toxin caused no change in cAMP levels after addition of $17,20 \beta-\mathrm{DHP}$ in both $\mathrm{mPR} \alpha$ - and $\mathrm{mPR} \beta$-expressing cell lines, implying no coupling to a $G_{s}$ protein (see Fig. 4 in Supplementary data).

\section{Discussion}

The research presented in this study lays the groundwork for future research to characterize the distinct roles of zebrafish $\mathrm{mPR} \alpha$ and $\mathrm{mPR} \beta$ in mediating the nongenomic functions of
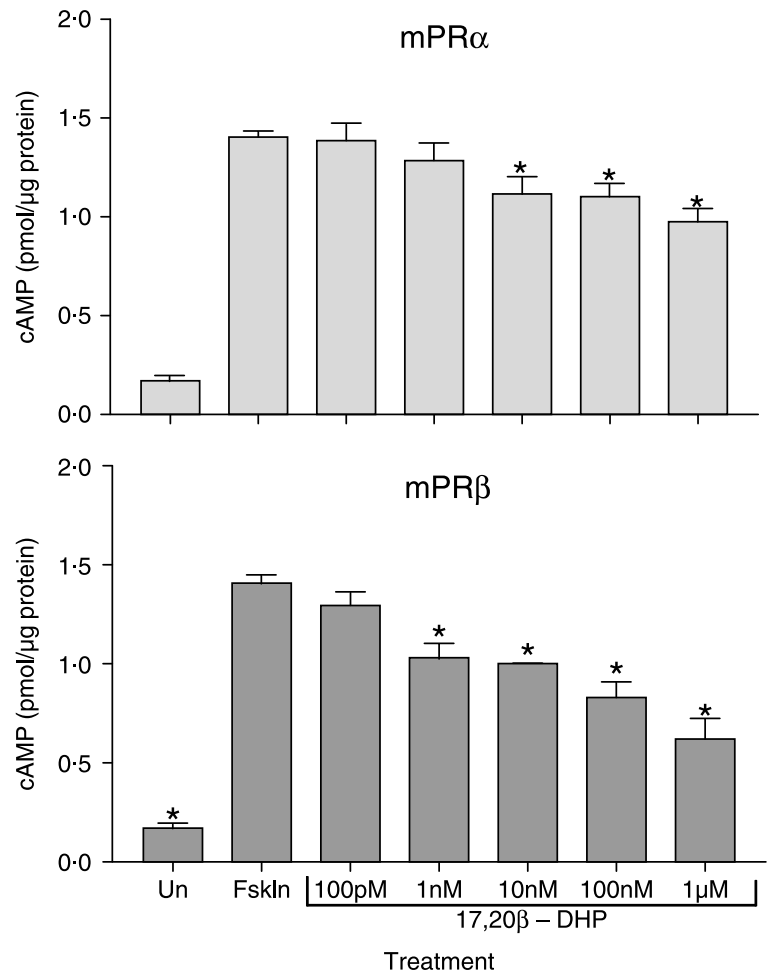

Figure 11 cAMP inhibition by various doses of 17,20ß-DHP for $15 \mathrm{~min}$ in $\mathrm{mPR} \alpha$ - and $\mathrm{mPR} \beta$-transfected cells. Samples were pretreated with $1 \mu \mathrm{M}$ forskolin (Fskln) for $15 \mathrm{~min}$ prior to addition of steroid (mean \pm s.E.M., $n=4, * P<0 \cdot 05$ ). Un, untreated control.

progestins in this species by identifying the signaling pathways and ligand specificity of zebrafish $\mathrm{mPR} \alpha$ and the previously uncharacterized mPR $\beta$. In previous research, the seatrout $\operatorname{mPR} \alpha$ was shown to rapidly mediate nongenomic signaling through activation of MAPK and inhibition of cAMP by a $\mathrm{G}_{\mathrm{i}}$-coupled pathway (Zhu et al. 2003a). In addition, findings with seatrout $\mathrm{mPR} \alpha$, and more recently with the $\mathrm{mPR} \alpha$ from goldfish, support the hypothesis that $\operatorname{mPR} \alpha$ acts as an intermediary in MIS induction of oocyte maturation in teleost fish (Zhu et al. 2003a, Tokumoto et al. 2006). The present research in the zebrafish further suggests that $\mathrm{mPR} \alpha$ signaling is conserved and is most significantly activated in response to the MIS through a $G_{i}$ inhibitory protein. Furthermore, the zebrafish $\mathrm{mPR} \beta$ was activated in a manner similar to $\mathrm{mPR} \alpha$ in response to the MIS, implying a possible similar role in mediating nongenomic progestin actions.

Cell-surface localization, specific mPR-binding activity, and potential nongenomic-signaling pathways initiated by progestins acting through zebrafish $\mathrm{mPR} \alpha$ and $\mathrm{mPR} \beta$ were identified by stably transfecting the nonprogestin responsive and nuclear progestin receptor-deficient MDA-MB-231 cell line with the receptors. Clear evidence was obtained for expression and cell-surface localization of the recombinant receptors by three independent methods, western blotting, flow cytometry, and biotin-surface labeling. Moreover, 

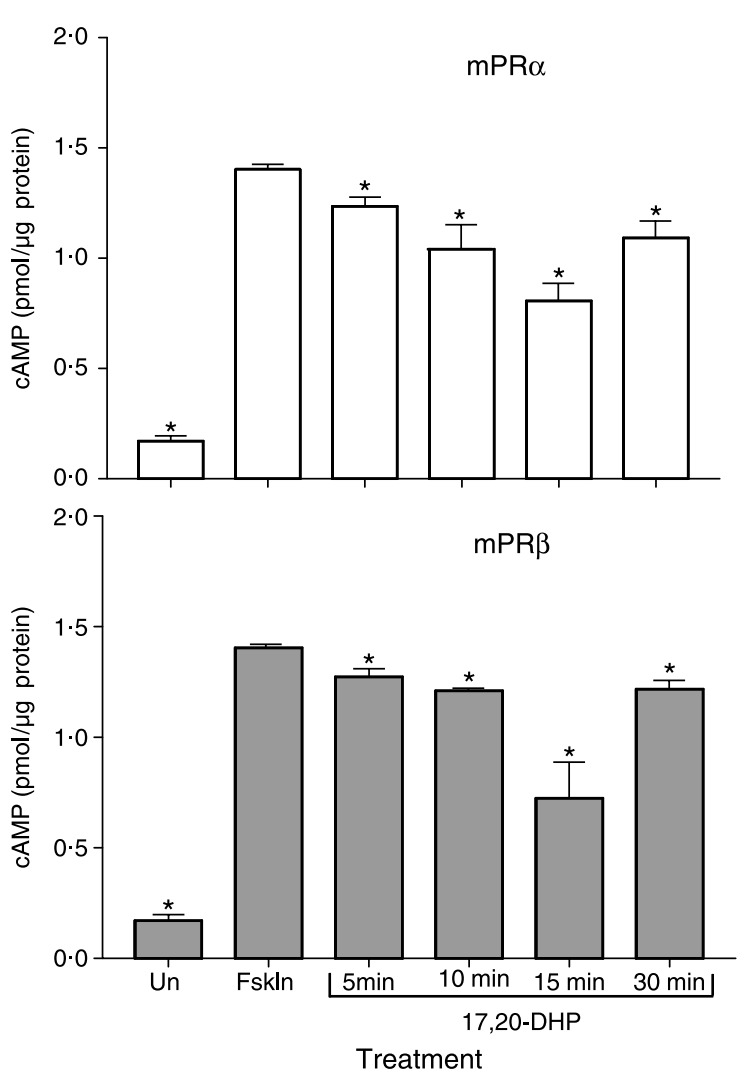

Figure 12 cAMP inhibition of $\mathrm{mPR} \alpha$ - and $\mathrm{mPR} \beta$-transfected cells at various time points after addition $1 \mu M$ 17,20ß-DHP. Samples were pretreated with $1 \mu \mathrm{M}$ forskolin (Fskln) for $15 \mathrm{~min}$ prior to addition of steroid (mean \pm s.E.M., $n=3, * P<0 \cdot 05$ ). Un, untreated control.

expression of both zebrafish $\mathrm{mPR}$ proteins was associated with marked increases in specific membrane-bound 17,20ßDHP. These binding moieties have characteristics typical of progestin membrane receptors. High affinity, saturable, displaceable, single-binding sites specific for 17,20 $\beta$-DHP, and other progestins were identified in plasma membrane preparations from both $\mathrm{mPR} \alpha$ - and $\mathrm{mPR} \beta$-transfected cells. In addition, a comprehensive series of experiments showed rapid activation of signaling pathways via $\operatorname{mPR} \alpha$ and $\operatorname{mPR} \beta$ after progestin treatment, indicating that the two $\mathrm{mPR}$ proteins can function as receptors in the transfected cells to transduce progestin signaling. Progesterone, together with the known MISs in fish, 17,20 $\beta$-DHP and $20 \beta-S$, significantly increased MAPK activity in receptor-transfected cells within $5 \mathrm{~min}$. The zebrafish MIS, 17,20ß-DHP, caused activation of MAPK for both receptors at lower concentrations (1-10 nM) compared with P4 (10-100 nM) and 20 $\mathrm{S}(1 \mu \mathrm{M})$. Furthermore, cAMP levels in both receptortransfected cell lines were significantly decreased in a concentration- and time-dependent manner in response to physiologically relevant concentrations of $17,20 \beta-\mathrm{DHP}$. Although circulating levels of 17,20ß-DHP have not yet
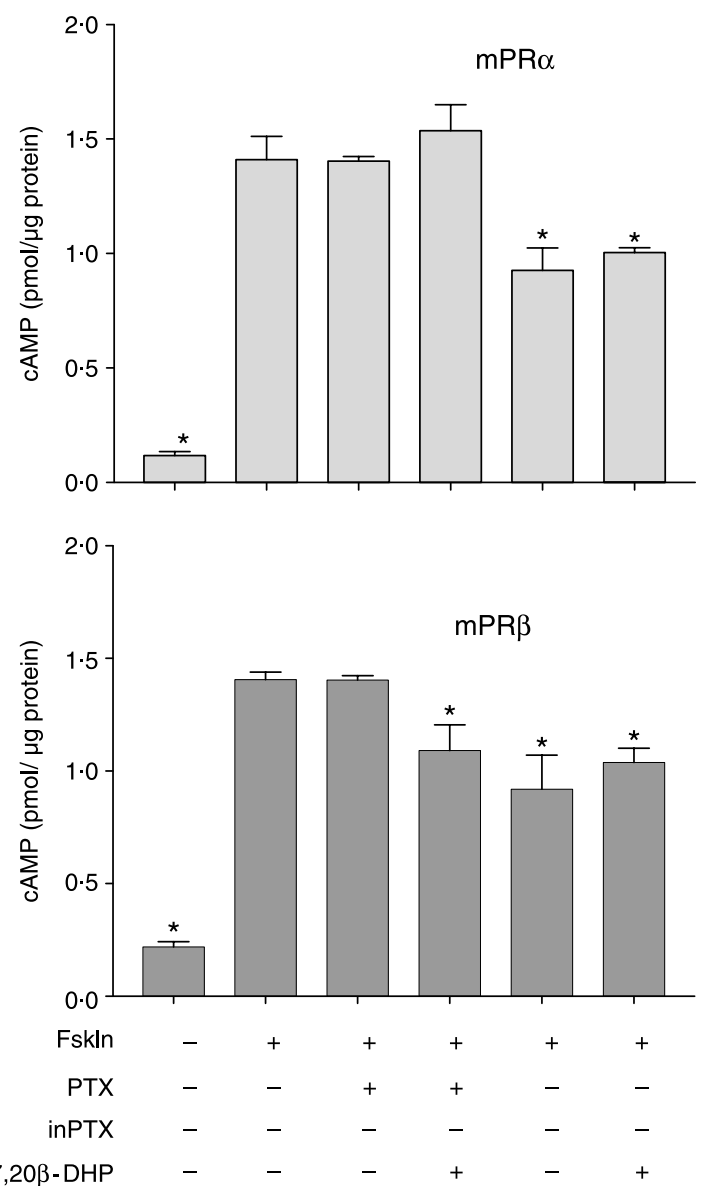

Figure 13 Effects of pertussis toxin on cAMP levels in $\mathrm{mPR} \alpha$ - and mPR $\beta$-transfected cells after 15 min stimulation with $1 \mu \mathrm{M} 17,20 \beta$ DHP. Samples were pretreated as indicated with $1 \mu \mathrm{M}$ forskolin (Fskln) for $15 \mathrm{~min}$ and $200 \mathrm{ng} / \mathrm{ml}$ active pertussis toxin (PTX) or inactive pertussis toxin (inPTX) for $12 \mathrm{~h}$ prior to the addition of steroid (mean \pm s.E.M., $n=3, * P<0 \cdot 05$ ).

been measured in zebrafish due to their small size, MIS concentrations $(1-10 \mathrm{nM})$ that were effective in significantly decreasing cAMP levels and activating MAPK in this experiment are within the range found in the plasma of a variety of fish species during oocyte maturation and ovulation (Kobayashi et al. 1987, Truscott et al. 1992, King et al. 1994). The finding that the MIS, 17,20 $\beta$-DHP, is the preferred ligand for the zebrafish mPRs is important for establishing their ovarian functions in the presence of a variety of similar progestin derivatives in the ovary. The observation that both the untransfected MDA-MB-231 cells and receptortransfected cells showed significant increases in MAPK in response to testosterone, and a significant decrease in cAMP levels in response to estrogen, raises the possibility that membrane receptors for these steroids are expressed in this cell line. However, no rapid signaling in response to progestins or corticosteroids was observed (see 
Supplementary data) in nontransfected cells. Taken together, the results provide clear evidence that both zebrafish $\mathrm{mPR} \alpha$ and $\operatorname{mPR} \beta$ can mediate rapid nongenomic actions of progestins and that this can occur independent of the nuclear progestin receptor since it is not present in this cell model (Horwitz et al. 1978).

Previous results showing co-localization of $\mathrm{mPR} \alpha$ and $\mathrm{mPR} \beta$ in the brain and reproductive tissues of zebrafish, and inhibition of oocyte maturation in this species by microinjection of antisense oligos to $\mathrm{mPR} \alpha$ and/or $\operatorname{mPR} \beta$ microinjection, support the suggestion that the receptors share common functions (Zhu et al. 2003a, Thomas et al. 2004, Kazeto et al. 2005). Zebrafish mPR $\alpha$ and $\operatorname{mPR} \beta$ may have a similar involvement in oocyte maturation to that proposed for the seatrout $\operatorname{mPR} \alpha$ and goldfish $\mathrm{mPR} \alpha$ as intermediaries in MIS induction of this process. The seatrout $\mathrm{mPR} \alpha$ is localized in the oocyte plasma membrane, its hormonal regulation and pattern of expression are consistent with its involvement in oocyte maturation, and the signal transduction pathway initiated through the receptor is the same as that identified during MIS induction of oocyte maturation in seatrout and other fish species (Nagahama 1997, Thomas et al. 2002, Zhu et al. $2003 a$, Pace \& Thomas 2005). In the zebrafish, mPR $\alpha$ and $\operatorname{mPR} \beta$ have been co-localized primarily in the ovaries, the receptors have been shown to be upregulated prior to oocyte maturation and antisense microinjections for both receptors have been shown to block MIS-induced oocyte maturation (Zhu et al. 2003a, Thomas et al. 2004, Kazeto et al. 2005, Kohli et al. 2005). In the present study, the zebrafish MIS shows the greatest activation of MAPK and inhibition of CAMP, signaling that is consistent with previous studies of fish oocyte maturation, through both zebrafish $\mathrm{mPR} \alpha$ and $\mathrm{mPR} \beta$. The $\mathrm{mPR}$ s have also been localized primarily on the plasma membrane in zebrafish oocytes, in agreement with the predicted localization of the MIS receptor.

The zebrafish is an excellent model for further examination of the actions of $\operatorname{mPR} \alpha$ and $\operatorname{mPR} \beta$ in oocyte maturation and early development, because it spawns daily, responds to a known MIS, develops rapidly, and their embryos survive externally. However, additional studies are required to demonstrate direct roles for each of the receptors in mediating MIS induction of ooctye maturation in vivo. Detailed information is also needed on the progestin-mediated signaling pathways involved in induction of oocyte maturation in this species, on the pattern of daily changes in receptor expression and functionality, and possible interactions between $\operatorname{mPR} \alpha$ and $\mathrm{mPR} \beta$. A better understanding of the functions mediated by the mPRs in zebrafish has the potential to significantly advance our understanding of progestin-mediated nongenomic signaling in vertebrate reproductive tissues. For example, $\operatorname{mPR} \alpha$ and $\operatorname{mPR} \beta$ have been localized in mammalian ovaries, where they may have similar roles in progestin signaling (Zhu et al. 2003b, Cai \& Stucco 2005).

\section{Acknowledgements}

This work was supported in part by the National Science Foundation Grant IBN-0315349 to Y Z and the EPA STAR Grant No R-82902401 to P T. We want to thank Prakash Peddi for the assistance with immunohistochemistry. The authors declare that there is no conflict of interest that would prejudice the impartiality of this scientific work.

\section{References}

Ausubel F, Brent R, Kingston R, Moore D, Seidman J \& Struhl K (Eds) 2000 Current Protocols in Molecular Biology. New Jersey, USA: Wiley.

Baldi E, Luconi M, Bonaccorsi L \& Forti G 1998 Nongenomic effects of progesterone on spermatozoa: mechanisms of signal transduction and clinical implications. Frontiers in Bioscience 3 1051-1059.

Blackmore PF \& Lattanzio FA 1991 Cell surface localization of a novel nongenomic progesterone receptor on the head of human sperm. Biochemical and Biophysical Research Communications 181 531-538.

Blackmore P, Beebe S, Danforth D \& Alexander N 1990 Progesterone and $17 \alpha$-hydroxyprogesterone novel stimulators of calcium influx in human sperm. Journal of Biological Chemistry 265 1376-1380.

Cai Z \& Stucco C 2005 Expression and regulation of progestin membrane receptors in the rat corpus luteum. Endocrinology $1465522-5532$.

Calogero AE, Palumbo MA, Bosboom AM, Burrello N, Ferrera E, Palumbo G, Petraglia F \& D'Agata R 1998 The neuroactive steroid allopregnanolone suppresses hypothalamic gonadotropin-releasing hormone release through a mechanism mediated by the gamma-aminobutyric acid $_{\mathrm{A}}$ receptor. Journal of Endocrinology 158 121-125.

Falkenstein E, Heck M, Gerdes D, Grube D, Christ M, Weigel M, Buddhikot M, Meizel S \& Wehling M 1999 Specific progesterone binding to a membrane protein and related nongenomic effects on $\mathrm{Ca}^{2+}$-fluxes in sperm. Endocrinology 140 5999-6002.

Fernandes MS, Pierron V, Michalovich D, Astle S, Thorton S, Peltoketo H, Lam EW, Gellersen B, Huhtaniemi I, Allen J et al. 2005 Regulated expression of putative membrane progestin receptor homologues in human endometrium and gestational tissues. Journal of Endocrinology 187 89-101.

Ferrell JE 1999 Xenopus oocyte maturation: new lessons from a good egg. BioEssays $21833-842$.

Fields TA \& Casey PJ 1997 Signalling functions and biochemical properties of pertussis toxin-resistant G-proteins. Biochemical Journal 321 561-571.

Horwitz K, Zava D, Thilangar A, Jensen E \& McGuire W 1978 Steroid receptor analyses of nine human breast cancer cell lines. Cancer Research 38 2434-2437.

Karteris E, Zervou S, Pang Y, Dong J, Hillhouse EW, Randeva HS \& Thomas P 2006 Progesterone signaling in human myometrium through two novel membrane $G$ protein coupled receptors: potential role in functional progesterone withdrawal at term. Molecular Endocrinology 20 1519-1534.

Kazeto Y, Goto-Kazeto R \& Trant JM 2005 Membrane-bound progestin receptors in channel catfish and zebrafish ovary: changes in gene expression associated with the reproductive cycles and hormonal reagents. General and Comparative Endocrinology 142 204-211.

King W, Thomas P, Harrell RM, Hodson RG \& Sullivan CV 1994 Plasma levels of gonadal steroids during final oocyte maturation of striped bass, Morone saxatilis L. General and Comparative Endocrinology 95 178-191.

Kobayashi M, Aida K \& Hanyu I 1987 Hormone changes during ovulation and effects of steroid hormones on plasma gonadotropin levels and ovulation in goldfish. General and Comparative Endocrinology 67 24-32.

Kohli G, Clelland E \& Peng C 2005 Potential targets of transforming growth factor-beta1 during inhibition of oocyte maturation in zebrafish. Reproductive Biology and Endocrinology 353.

Kostellow AB, Ziegler D \& Morrill GA 1980 Regulation of $\mathrm{Ca}^{2+}$ and cyclic AMP during the first meiotic division in amphibian oocytes by progesterone. Journal of Cyclic Nucleotide Research 6 347-358. 
Losel RM, Falkenstein E, Feuring M, Shultz A, Tillmann H, Rossol-Haseroth K \& Wehling M 2003 Nongenomic steroid action: controversies, questions, and answers. Physiological Reviews 83 965-1016.

Luconi M, Francavilla F, Porazzi I, Macerola B, Forti G \& Baldi E 2004 Human spermatozoa as a model for studying membrane receptors mediating rapid nongenomic effects of progesterone and estrogens. Steroids $69553-559$.

Majewska MD, Harrison NL, Schwartz RD, Barker JL \& Paul SM 1986 Steroid hormone metabolites are barbiturate-like modulators of the GABA receptor. Science 232 1004-1007.

Nagahama Y 1997 17 $\alpha, 20 \beta$-Dihydroxy-4-pregnene-3-one, a maturationinducing hormone in fish oocytes: mechanisms of synthesis and action. Steroids 62 190-196.

Norman AW, Mizwicki MT \& Norman DPG 2004 Steroid-hormone rapid actions, membrane receptors and conformational ensemble model. Nature Review Drug Discovery 3 27-41.

Pace MC \& Thomas P 2005 Activation of a pertussis toxin-sensitive, inhibitory G-protein is necessary for steroid-mediated oocyte maturation in spotted seatrout. Developmental Biology 285 70-79.

Patiño R \& Thomas P 1990a Effects of gonadotropin on ovarian intrafollicular processes during the development of oocytes maturational competence in a teleost, the Atlantic croaker. Evidence for two distinct stages of gonadotropic control of final oocytes maturation. Biology of Reproduction $\mathbf{4 3}$ 818-827.

Patiño R \& Thomas P $1990 b$ Characterization of membrane receptor activity for 17 $\alpha, 20 \beta, 21$-trihydroxy-4-pregnen-3-one in ovaries of spotted seatrout (Cynoscion nebulosus). General and Comparative Endocrinology 78 204-217.

Pietras RJ \& Szego CM 1975 Endometrial cell calcium and oestrogen action. Nature 253 357-359.

Sabeur K, Edwards DP \& Meizel S 1996 Human sperm plasma membrane progesterone receptors and the acrosome reaction. Biology of Reproduction $\mathbf{5 4}$ 993-1001.

Scott AP, Sheldrick EL \& Flint APF 1982 Measurement of $17 \alpha, 20 \beta$-dihydroxy4-pregnen-3-one in plasma of trout (Salmo gairdneri Richardson): seasonal changes and response to salmon pituitary extract. General and Comparative Endocrinology 46 444-451.
Sim JA, Skynner MJ \& Herbison AE 2001 Direct regulation of postnatal $\mathrm{GnRH}$ neurons by the progesterone derivative allopregnanolone in the mouse. Endocrinology 142 4448-4453.

Tang YT, Hu T, Arterburn M, Boyle B, Bright JM, Emtage PC \& Funk WD 2005 PAQR proteins: novel membrane receptor family defined by an ancient 7-transmembrane pass motif. Journal of Molecular Evolution $\mathbf{6 1}$ 372-380.

Thomas P, Zhu Y \& Pace M 2002 Progestin membrane receptors involved in the meiotic maturation of teleost oocytes: a review with some new findings. Steroids 67 511-517.

Thomas P, Pang Y, Zhu Y, Detweiler C \& Doughty K 2004 Multiple rapid progestin actions and membrane receptor subtypes in fish. Steroids $\mathbf{6 9}$ $567-573$.

Thomas P, Tubbs C, Detweiler C, Das S, Ford L \& Breckenridge-Miller D 2005 Binding characteristics, hormonal regulation and identity of the sperm membrane progestin receptor in Atlantic croaker. Steroids 70 427-433.

Tokumoto M, Nagahama Y, Thomas P \& Tokumoto T 2006 Cloning and identification of a membrane progestin receptor in goldfish ovaries and evidence it is an intermediary in oocyte meiotic maturation. General and Comparative Endocrinology 145 101-108.

Truscott B, So YP, Nagler JJ \& Idler DR 1992 Steroids involved with final oocyte maturation in the winter flounder. Journal of Steroid Biochemistry and Molecular Biology 42 351-356.

Zhu Y, Rice C, Pang Y, Pace M \& Thomas P 2003a Cloning, expression, and characterization of a membrane progestin receptor and evidence it is an intermediary in meiotic maturation of fish oocytes. PNAS 100 2231-2236.

Zhu Y, Bond J \& Thomas P $2003 b$ Identification, classification, and partial characterization of genes in humans and other vertebrates homologous to a fish membrane progestin receptor. PNAS 100 2237-2242.

\section{Received in final form 24 April 2006 \\ Accepted 9 May 2006 \\ Made available online as an Accepted Preprint 29 May 2006}

